University of Nebraska - Lincoln

DigitalCommons@University of Nebraska - Lincoln

Faculty Publications: Department of Teaching, Department of Teaching, Learning and Teacher Learning and Teacher Education

Education

$11-2003$

\title{
Reforming Elementary Science Teacher Preparation: What about Extant Teaching Beliefs?
}

Julie A. Thomas

Texas Tech University, julie.thomas@unl.edu

Jon E. Pedersen

University of Nebraska-Lincoln, jpedersen2@unl.edu

Follow this and additional works at: https://digitalcommons.unl.edu/teachlearnfacpub

Part of the Teacher Education and Professional Development Commons

Thomas, Julie A. and Pedersen, Jon E., "Reforming Elementary Science Teacher Preparation: What about Extant Teaching Beliefs?" (2003). Faculty Publications: Department of Teaching, Learning and Teacher Education. 89.

https://digitalcommons.unl.edu/teachlearnfacpub/89

This Article is brought to you for free and open access by the Department of Teaching, Learning and Teacher Education at DigitalCommons@University of Nebraska - Lincoln. It has been accepted for inclusion in Faculty Publications: Department of Teaching, Learning and Teacher Education by an authorized administrator of DigitalCommons@University of Nebraska - Lincoln. 


\section{Reforming Elementary Science Teacher Preparation: What About Extant Teaching Beliefs?}

A common maxim in the educational profession is that one teaches the way one is taught. Indications are that preservice teachers' beliefs, attitudes, and practices may be linked to previous experiences. Calderhead \& Robson (1991) underscored this concern by asserting that teachers use gocd teachers as models for developing their own images as teachers. Others have argued that the images held by teachers are used as frames of reference for their own teaching practices. In this article, preservice teachers' perceptions of themselves as science teachers are examined. The assertion is made that a long history of stereotypical science learning experiences - in elementary school, high school, and college - powerfully impacts the way in which elementary preservice teacheirs understand the nature of science and come to believe science should be taught. In the current study, the images and perceptions preservice teachers bring to science methods courses (as evidenced in drawings of themselves as science teachers at work) are identified and ways these images and perceptions may have been formed and how they can be reinforced or modified during a science methods course are discussed.

Over the past three or more decades, much has been written about teacher education and the preparation of elementary science teachers. Many national reports have led to reforms in science and mathematics education and have focused attention on the efficacy of science and mathematics teacher preparation programs in the United States (Simmons et al., 1999); some of these focused on teachers' attitudes and beliefs regarding the teaching of science and science, in general. Such reports and continuing research indicate that teacher preparation programs have had little impact on the beliefs and practices of our preservice students (Raizen \& Michelsohn, 1994). Certainly, methods courses alone are not the sole source of learning how to teach (Bryan, Abell, \& Anderson 1996b). A number of research findings have led to some changes in methods courses - such as increasing the number of field experience hours in classrooms. It appears, however, that these efforts have fallen short.

Science educators currently design teacher preparation largely according to constructivist perspectives. Constructivism, in general, maintains that knowledge is constructed as teachers and students interact with (and build on) their own messages and actions across the everyday events in classrooms (Ullrich, 1999a). It also seems that prospective teachers "pick and choose content they will respond to according to prior knowledge about teaching and learning developed while they were students in elementary, high school, and college classrooms" (Ullrich, 1999a, p. 1). Content and experiences confirming their preexisting schemata are embraced, while those that do not are ignored, or perhaps more accurately, politely suffered through and then discounted (Ullrich, 1999b, p. 19). In this way: prior knowledge about teaching acts as a filter o: lens through which preservice teachers take astion. Preservice teachers are more likely to take action on content or experiences that confirm their preexisting schemata of how to teach, while other perspectives, particularly ones that are critically oriented, are discounted(Bullough, 1994).

\section{Theoretical Perspectives}

The research described in this article is grounded in the theoretical perspectives of teacher beliefs, episodic memory, and reform in teacher preparation.

\section{Teacher Beliefs}

Past experiences help preservice teachers build attitudes, personal theories, and beliefs regarding the teaching of science. These beliefs can be described as personal convictions, philosophies, tenets, or opinions about teaching and learning (Czerniak, Lumpe, \& Haney, 1999). These attitudes, personal theories, and beliefs organize strongly held images of self as a teacher. 
Perceptions of ability and capability, linked to prior conceptualizations, form internal, mental models of interaction (Norman, 1983). According to Norman, internal mental models depend heavily on an individual's own conceptualization of self and influence the selfperception of a teacher's capability and ability. Norman explained that these images or mental models provide (a) a belief system, reflecting beliefs acquired through observation, instruction, or inference; (b) observability, providing correspondence between the mental model and the physical world; and (c) predictability, allowing a person to understand and anticipate the behavior of a physical system.

Barnes (1992), noting that one has a set of interconnected expectations before entering a school room, suggested that mental models are organized clustered sets or frames of expectations. As he explained, teachers' professional frames are both individually and socially derived - shaped by experiences as well as by expectations and values. From early experiences as students, teachers develop vivid images of teaching, according to Calderhead and Robson (1991). These images of good teaching and perceptions of personal skills affect students' interpretations of course experiences and powerfully influence the translated knowledge and projected practices they will apply as teachers. "Respected teachers, similar to the student himself or herself, seemed to reinforce the model; this was the kind of teacher they could see themselves becoming" (p. 4).

Thus, preservice teachers reference personal images to guide or shape their beliefs about teaching. If, metaphorically speaking, students come to our classes to build a house, and they enter the classroom having already framed, roofed, and finished their house, we can influence the color scheme and the floor coverings - but can do little to change their prebuilt house. So it is with teaching. Bullough \& Knowles (1991) also found that beginning teachers sought confirmation of their own personal images.

\section{Episodic Memory}

Nespor (1987) differentiated between knowledge and beliefs arguing that knowledge information is semantically stored, whereas beliefs reside in episodic memory drawn from experience. Nespor held that beliefs drew their power from previous episodes or events that influenced the understanding of subsequent events. The implications of episodic memory within belief systems are especially important to the current research, inasmuch as these critical episodes or experiences are believed to influence and frame how one learns and how one uses what is learned. Nespor contended that these richly detailed, episodic memories later serve as an inspiration or a template for one's own teaching practices. Other researchers have also noted the episodic nature of beliefs (Calderhead, 1988; Calderhead \& Robson, 1991; Clark, 1988; Goodman, 1988). Their studies suggested that students' educational beliefs significantly influence the perceptions and judgments they make about their own and others' teaching, as well as their interpretation and development of professional knowledge.

\section{Reforming Teacher Preparation}

Educating teachers is a process of building on, extending, and reconstructing past experience - particularly schooling experiences (Dewey, 1904; 1938). Years of school experiences, both as students and potential teachers, have established a strong set of beliefs regarding the teaching of science. The goal of science educators is to challenge students' views and work collectively to see them eventually embrace new perspectives. "In shifting the way we prepare teachers for professional practice, we may enable our students to confront, shift, and/or refine the beliefs, knowledge, values and assumptions that form their personal theories about teaching and learning" (Bryan, Abel, \& Anderson, 1996a, p. 3).

Bryan et al. (1996a) proposed teacher reflection as a reform process of "thinking and acting on those aspects of teaching that frustrate, confuse, and perplex" (p. 3). Engaging preservice teachers in reflection on their own views of learning and teaching (focused on their beliefs and classroom actions), allows greater insight into the kinds of experiences on which teacher education programs should be built to promote inquirybased teaching (Simmons et al., 1999).

Ullrich (1999a) used ajigsaw metaphor to describe preservice teacher reflection. He suggested, "We are asking prospective teachers to create a picture [of learning and teaching] out of a set of jigsaw pieces, with no picture to guide them, and no guarantee that the pieces would even make a picture" (p. 3). Apparently students would rely on past experiences to collect images for their metaphorical jigsaw puzzle - a picture based on episodic memories of their own experiences in the classroom. Students are most easily influenced by people and experiences that legitimatize their intuitive screen, according to Goodman (1988). Therefore, there is cause for concern that higher education classrooms, like those in students' K-12 experiences, will be more likely to reinforce students' prior beliefs than to adjust them. 
These theoretical perspectives and our personal experiences as elementary science methods faculty, help us envision a model (see Figure 1) for the "how" and "when" of science methods courses. Many factors shape the learning of preservice elementary science teachers; certainly previous life experiences impact the way in which each preservice teacher experiences a science methods course. In the interest of science education reform, it is important to help preservice teachers reframe their experience-linked thinking.

Earlier research (Thomas \& Pedersen, 1998) found a significant difference in the means $(p<.000$ and $p<$ .001 ) of the paired precourse and postcourse Draw-aScience-Teacher-Test Checklist (DASTT-C) scored drawing samples. This apparently means that preservice teachers' perceptions of themselves as elementary science teachers were more student-centered and less teacher-centered by the end of the semester course. In the present research, we were interested in knowing whether students' drawings of themselves as elementary science teachers encouraged or enhanced the process of negotiation and renegotiation regarding their ideas and perceptions of elementary science teaching. The emphasis of this research was on the identification of the images and perceptions preservice teachers bring to science methods courses, how students come to imagine drawings of themselves as science teachers, and how or when students choose to draw different pictures of themselves as science teachers by the end of a semester course.

\section{Research Questions/Design}

Our research is connected to the aforementioned research regarding student perceptions of thems:elves as science teachers and episodic memory. We hypothesized that a long history of stereotypical science learning experiences - in elementary school high school, and college - powerfully impacts the way in which elementary preservice students understand the nature of science and come to believe science should be taught. We want to help students identify their beliefs

Figure 1. Experience, memory, and the challenge of field experiences.

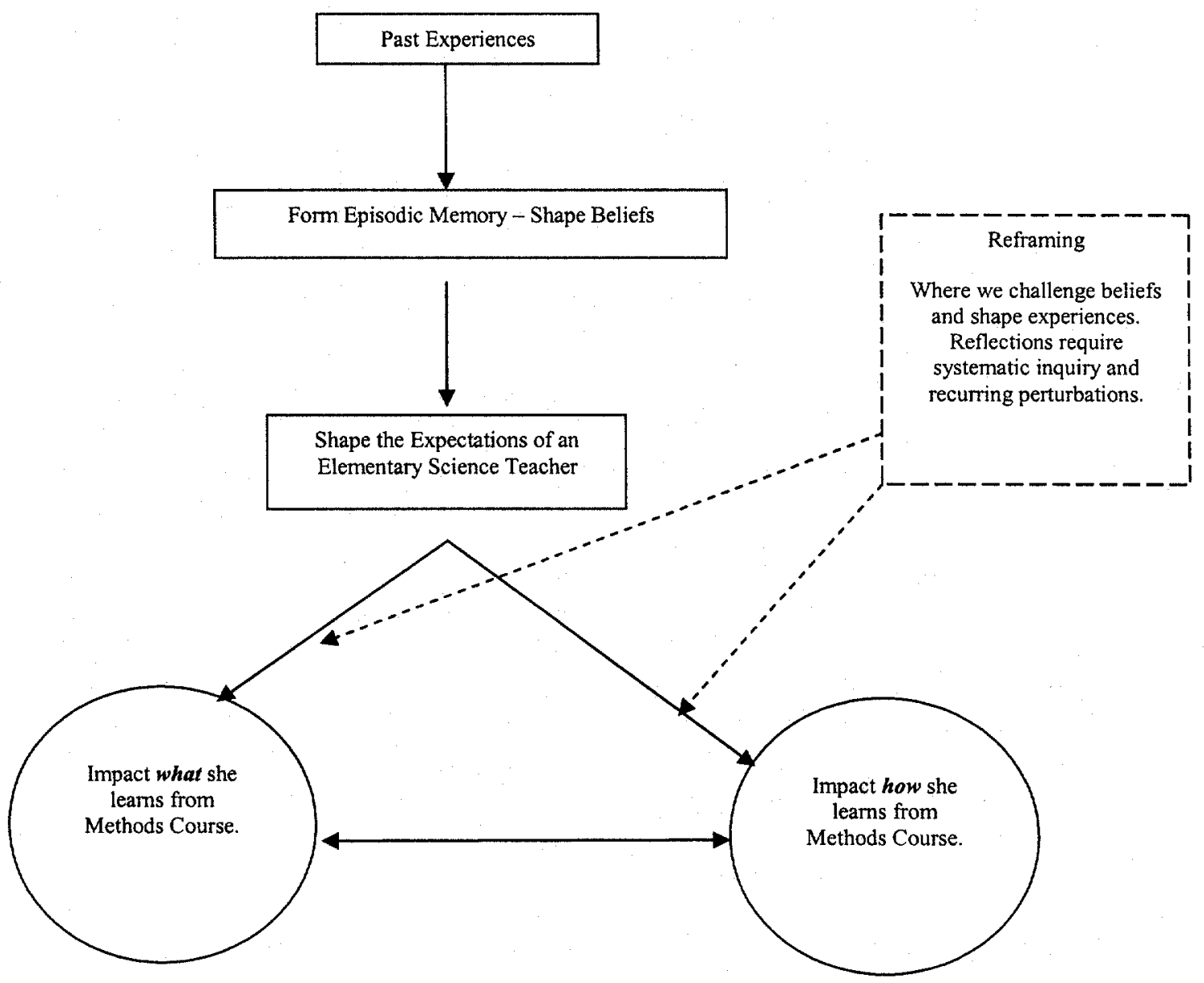

Volume 103(7), November 2003 
and have opportunities to modify them while they participate in campus or field experiences (in elementary classrooms) during the semester in which they are enrolled in our science methods courses. We begin by identifying the images and perceptions preservice teachers brought to our science methods courses (as evidenced by drawings of themselves as science teachers at work) and attempt to determine how these images and perceptions formed and how they were reinforced or modified during the semester. The research questions were as follows:

1. What image do elementary preservice teachers have of themselves as elementary science teachers?

2. What defines the science learning experiences of preservice elementary teachers?

3. How do the students modify their ideas about themselves as science teachers by the end of a methods course semester?

For this research, the DASTT-C instrument (using the form checklist found in Thomas, Pedersen, \& Finson, 2001) was used to measure preservice teachers' perceptions of elementary science teaching. Validity and reliability measures found no significant difference in any of the subscores or total scores of the DASTT$C$ (using ANOVA), and scores were found to be internally consistent (using Kuder-Richardson 20). This test is drawn from the Draw-a-Man Test (Goodenough, 1926), a measure of intelligence, the Draw-a-Scientist Test (Chambers, 1983), an open-ended projective test to provide information regarding children's illustrations of scientists, and the Draw-a-Scientist-Test Checklist (DAST-C; Finson, Beaver, \& Cramond, 1995), which was later developed to facilitate ease of assessment.

Structurally, the DASTT-C instrument directs a preservice teacher to "draw a picture of yourself as a science teacher at work" and write a brief explanation of the drawing. The drawing is scored according to a 13-item dichotomous checklist (present or not present) that focuses on three aspects of the teaching-learning process: the teacher, the students, and the teaching environment. The Teacher Section of the DASTT-C instrument is divided into two subsections that focus on the teacher's activity (demonstrating, lecturing, using visual aids, etc.) and the teacher's position (location with respect to students, such as at the head of the classroom, and posture). The Students Section of the instrument is likewise divided into two subsections focusing on the activities of students (passively receiving information, responding to the teacher) and students' positions (seated within the classroom). The third section, Environment, consists of elements typically found inside classrooms, such as desks arranged in rows and symbols of teaching (chalkboards) and of science (science equipment), etc.

Total checklist scores can range from 0 to 13 (the higher the score, the more teacher-centered the image). More teacher-centered illustrations (higher scores) show the teacher in front of the class, teaching from a chalkboard, lecturing or showing students the lesson steps they will follow. These classrooms display the traditional rows-placement of desks or chairs, but even when children are grouped they are working in a different area of the classroom than the classroom teacher. These images fit with teacher-centered thinking about subject matter knowledge being central to the learning process led by a teacher who organizes and delivers learning. More student-centered illustrations (lower scores) show teachers doing activities with children, a classroom organization that includes more than the usual desks and chairs. These images fit more closely with standards-oriented or student-centered teaching following an exploratory approach to learning that encourages inquiry and questions facilitated by the teacher. Earlier research suggested that there are meaningful, personal stories to explain the details of the classrooms, work arrangements, lessons, and people preservice teachers choose to illustrate (Thomas \& Pedersen, 1998).

\section{The Study}

This study is both comparative and descriptive in nature, as it follows a mixed methodological design. It follows the participant-as-observer model (Spradley, 1980 ), as one of the researchers was also a methods course instructor. Data included multiple resources to strengthen reliability and internal validity (as recommended in Merriam, 1988). Qualitative and quantitative data were collected and analyzed separately but concurrently throughout the study. Creswell (1994) referred to this method as "simultaneous triangulation" (p. 182).

Triangulated data includes DASTT-C scores, written narrative responses to a personal history inventory, and selected participant interviews. Internal validity is ensured in the detailed research plan, clarification of researcher bias, triangulation of data, and member checks (as recommended in Spradley, 1980). This mixed-methods study relies on the strengths of both the qualitative and quantitative research paradigms and follows the dominant-less dominant design of Qual+ quan (Creswell, 1994). The lesserquantitative-component (DASTT-C scores) identifies current perceptions and beliefs of the participants. The 
greater-qualitative-component (personal histories and interviews) is developed as a descriptive case study, fleshing out the unique science learning experiences students bring to the methods course and the way in which students view images of themselves as elementary science teachers by the end of the course. According to Yin (1995), the case study component allows this research to "explain causal links in real-life interventions that are too complex for the survey or experimental strategies" ( p. 25).

One hundred fifty elementary preservice teachers were collectively selected from a southeastern and a southwestern university. This selection of students, similar in that they were all beginning their elementary science methods course in a constructivist-oriented teacher preparation program, supplied the large sample size necessary for quantitative analysis. On both campuses, students participated in professor-led, hands-on, inquiry-based science methods activities before teaching science lessons during a 3-4 week placement in an elementary classroom.

On the first day of class, all students were asked to "draw a picture of yourself as a science teacher at work" and write a brief explanation of the drawing. Students also filled out a brief, personal history form designed to elicit information about science courses completed and evaluative comments related to prior science learning experiences. This data set focused on the DASTT-C drawings and the unique science learning experiences of all students at the beginning of the semester.

At the end of the semester, a small sample (6 of the 150 precourse students) agreed to "draw a picture of yourself as a science teacher at work" postcourse and to record interviews as they discussed and compared their precourse and postcourse illustrations. Precourse and postcourse sample sizes differed, though each followed its respective research tradition. As Duemer et al. (2002) explained, studies of small samples lay a heavy burden on researchers to justify their conclusions. Findings are best understood as working hypotheses, and transferability is dependent on contextual fit (Lincoln \& Guba, 1985).

\section{Results}

The results of this study are presented in the following sequence: (a) the precourse images and perceptions of preservice elementary teachers entering our college methods courses; (b) the precourse science learning experiences of preservice elementary teachers entering our college methods courses; and (c) experiences that influenced, shaped, and guided the

students' thinking about elementary science teaching.

Images and Perceptions of Preservice Teachers

DASTT-C data indicate that teachers entered methods courses with a fixed image of themselves as science teachers. Just as Chambers (1983) found that children have a fixed image of a scientist by the fifth grade, preservice science teachers' images portrayed similarly well-defined teachers. This is clearly indicated in Tables 1, 2, and 3 showing the mean DASTT-C scores of the preservice teachers' drawings. Table 1 shows preservice teachers' mean DASTT-C scores on five aspects of teacher behaviors: demonsirating, lecturing, using visuals, location in the classroom, and posture (standing or sitting). These preservice teachers overwhelmingly saw themselves as the central figure in front of the classroom - standing to demonstrate an activity or presenting information to their students.

Table 2 shows preservice teachers' mean DASTT$\mathrm{C}$ scores according to three aspects of student behaviors: watching/listening, responding to the teacher or text, and posture (sitting or standing). Students in the drawings were primarily watching the teacher which reinforces the notion derived from the data in Table 1). The students were sitting in desks, usually ir. rows, looking in the direction of the teacher (suggesting a teacher-centered belief). Few drawings placed students in the center of the picture.

Table 3 shows preservice teachers' mean DASTT-

Table 1
Mean Scores of the DASTT-C Teacher Section

Teacher Measures

Teacher Demonstrating

Teacher Lecturing

Teacher Using Visuals

Teachers Centrally Located

Teacher Standing Erect
Meaniscore

$4:$

.90

.90

$9 !$

9)

\section{Table 2}

Mean Scores of the DASTT-C Student Section

\section{Student Measures}

Students Watching

Students Responding

Students Seated
Mean Score

$9 !$

33

$.6 "$ 


\section{Table 3}

\section{Mean Scores of the DASTT-C Environment Section}

\section{Environment Measures}

Desks in a Row

Displays Teacher Desk

Lab Organization

Displays Teaching Symbols

Displays Science Symbols

\section{Mean Score}

.56

.54

.36

.67

.74
$\mathrm{C}$ scores on five aspects of classroom environment: orientation of teacher desk, laboratory material placement, symbols of teaching, and symbols of science. Although not all of the students drew classrooms with desks in rows, the mean scores for classroom environment indicate that a majority of the preservice teachers believed this organization helps students engage in science learning. Moreover, these teachers held the science equipment on their own desk. There were few examples of students with materials or equipment at their desks or in their hands. Additionally, some pictures even showed the students having to "look up" to the table to see the equipment. Overall, these preservice teachers showed themselves standing in a classroom, at a chalkboard, in front of rows of students, planting bean seeds, leading students on nature walks, managing science learning centers, and presenting lectures or giving "read the book and answer the questions" directions.

Given the nature of these scores, it is safe to say that the trend among this population of students was slanted toward a more teacher-centered view of teaching - one in which the teacher initiates activities and assists students' learning according to specific outcomes focused on science content knowledge. Although this may be representative of the science learning experiences these preservice teachers have experienced, one might expect reform-oriented beliefs would cause students to picture a student-centered classroom - exploratory and investigative opportunities with a focus on student questions and group discussions focused on the scientific process.

\section{Precourse Science Learning Experiences}

An item analysis of all students' personal history with science learning experiences indicated that most participants completed two to three high school science courses and two to three college science courses.
Students connected the science learning experiences they remembered and the kind of science teaching they expected of themselves. For example, one student wrote about her "favorite and most effective teachers," explaining they did "exciting and worthwhile" science. She hoped she would be able "to come up with good ways to give children hands-on experience, motivate them, and show them the importance and usefulness of science in their daily lives." Most students expressed concern about their own limited content knowledge and worried about having "enough knowledge" of science to teach science "or help the children understand."

Many students reported negative science learning experiences. In this, students equated making a "bad grade" with a science learning/teaching inability on their part. Students who remembered watching videos and completing worksheets were "bored by science" and concerned they "don't know how to make it more interesting for my students." Sometimes a student proposed a specific teacher's approach to a changed learning experience for them. As one student wrote,

I did not enjoy science until junior high. In elementary school, teachers made us read from the book and answer questions from the chapter. In junior high, I had a wonderful teacher who made learning fun. He inspired me to become a teacher.

"Fun" was often understood as a critical attribute of good science learning and was used to describe a good science teacher.

\section{Influential Science Experiences}

Six randomly selected science methods course students agreed to an interview session at the end of the semester. Students were asked to create and discuss a postcourse drawing and identify and explain their understanding of any differences between the precourse and postcourse drawings. From these interviews we concluded that the students knew their pictures well. These drawings did not happen by chance but had specific meaning to the individual creator. All of the students recalled the pictures they had drawn at the beginning of the semester and made statements like, "Yes, that is what I thought," or "Oh, I remembered the students were doing a different lesson." However, all students indicated that there was a purpose for choosing the lesson they illustrated.

Although one student indicated that she drew students standing because she did not draw very well and did not know how to draw them in any other position, the others simply told about how they linked memories and images. The stories behind the illustrations came from either positive personal experiences (which 
these preservice teachers wanted to repeat for their students) or negative personal experiences (which they wanted to modify or improve when they repeated it for their students). In the following excerpts, preservice students explain how they got the idea for their picture:

I am making ice cream with my students. We did it in high school chemistry my sophomore year. I even remember we used Folgers coffee cans.

We are doing a dinosaur lesson and [the children are] touching, holding the bones. We did a dinosaur lesson in elementary school and didn't get to touch the bones. I just remember thinking, "Let me see one!"

One of my memories from elementary school is in third or fourth grade. We went to this park. We were studying trees, [picking off the bark] and comparing the bark and leaves [just like the children in this picture]. We did an art project later-a rubbing with crayons.

Other students rationalized their pictures as being different from their own experiences. One student explained that she mostly remembers field trips in junior high school when "we got to touch and do things handson." Another student had created an abstract image and explained that the hands were her "teacher hands" and the eyes belonged to the children, and the stars, moon and water represented the things she wants to teach them. She further explained, "After I finished the picture, I realized I was supposed to draw myself but I didn't think of it like that." She seemed to illustrate her beliefs without drawing herself. One student explained she had gotten her illustration idea from the Internet. In this study of birds, she explained, "That would be so cool. You know ... real life experiences. I didn't have any science excitement. Maybe that's why I was thinking [like that]."

Three themes emerged in the analysis of these transcripts following open coding procedures and the constant comparative protocol described by Strauss and Corbin (1990).

Teaching is "easy smeasy." The Teaching is Easy Smeasy theme came through as individuals related their pictures to always liking school. They knew from an early age that they were going to be teachers, and this was reinforced by parents and other significant individuals in their lives. Commonly, they alsolinked this early memory to episodes and experiences in their own lives (such as teaching to stuffed animals and dolls or to actual classroom experiences). For example, Kim's precourse picture included many of the science learning activities she remembered from her own high school science learning. She told stories about "blowing things up" and "building a space station out of popsicle sticks." Kim has "always enjoyed science" and expected to "pose questions back" to the children when she does not know the answers to their questions.

In contrast, Laura's classroom illustrations look a little like blueprints. When asked to draw a picture at the end of the semester, Laura wondered, "Can we just draw the same picture again?" Then Laura remembered that it was easier for the teacher to get between round tables rather than rectangular tables and that she had wished for extra sinks in her field experience classroom. Laura wanted lots of class space wit tiled areas and carpeted areas. As she told the stories of her pictures, Laura explained,

I think I was born [to be a teacher]. Because I had been teaching every kid in our neighborhood since Iwas old enough to talk and organize themall. They liked it, so I gave them games. I came up with all the story ideas and we had an imaginary world [acting out my stories]. My Mom says I was born to do what I'm doing.

Laura was very sure of her teaching ideas and her teaching competencies. These beliefs have been reinforced since she was "old enough to talk."

Field-experiences are confirming. The theme, Field Experiences Are Confirming, became evident as individuals talked about their own teaching experiences. Many linked the stories and explanations in their drawings to the actual "doing it" (teaching). They explained that the experiences were confirming in providing them the opportunity to learn froml what works. For example, both of Rebecca's pictures indicated a fieldtrip science lesson. Rebecca explained,

I would definitely want to incorporate field trips because seeing and doing is an important part in children's learning. Those are the events I remembered - those are the things that really stuck out in my mind. So, as a teacher, I feel like those kinds of experiences are going to be important for me to incorporate into my science teaching.

Rebecca's cooperating teacher took her first graders on a neighborhood "field trip" during Rebecca's field experience. She was impressed with how excited the children were about picking up the leaves and how well the classroom teacher integrated the leaves into classroom activities once they returned. Rebecica explained, "You know, she just carried that back into the classroom. Because I feel the children participated in something that was very much hands-on and they went outside exploring, I think that's something that will be very memorable to them." Rebecca had good learning 
experiences on field trips and she expected (and saw) that all children have good learning experiences on field trips. She explained, "It's the best semester I've ever had."

Describing her precourse illustration, Carrie offered, "Well, it could be anywhere-just by trees or collecting butterflies, actively doing something-not just inside the classroom." When a teacher desk in her postcourse illustration was pointed out to her, she explained,

This is definitely from my field experience. This is me actually teaching. This is how I would look at it and this is how I would see myself. This is how I taught. I stood right here. Here was her table and here were her students. This was just kind of looking down on them. Here I could actually picture myself.

Carrie's teaching in her field experience allowed her to define "organized" group experiences (as opposed to the outdoor activity she drew at the beginning of the course). She realized she wanted "a little bitmore structure" than she originally thought.

Fun, hands-on science is the best. The last theme to emerge from the stories and interviews was Fun Hands-on Science Learning is the Best. As preservice teachers told their stories, it was obvious that having fun with science was an important aspect of their future classrooms. They related events in their own experience in which they enjoyed a class or a teacher. Within these instances, both who the teacher was (friendly, fun, energetic) and what the teacher did (blowing bubbles, allowing students to touch, feel, participate) were critical aspects. Moreover, as the individuals discussed their pictures, it was clear (in their view) that if students were having fun they were learning. Little reference was made to the national standards or children's understanding of science in describing the pictures they drew - though these issues were basic strands in the methods course they had just completed.

Kim's and Leslie's stories provide examples of this theme. In her postcourse illustration, Kim was blowing bubbles (the same activity she organized for her field experience). She explained, "I know some things have to be boring, but bubbles is the class I enjoyed the most." Leslie's postcourse picture illustrated a lesson she actually taught in her field experience classroom. Her kindergartners are observing a rabbit interact with their classroom turtle. Leslie was proud of following the children's idea of putting the two animals together. She explained,

I didn't really have anything in mind when I was drawing the prepicture. But I think that if I'm in control of the lesson and it's real structured - I worry that if I mess up, then they're not really learning anything. [But] I mean, if they do it and mess up, then I think they would still learn something.

Leslie was explaining a changed understanding of control in a primary lesson. She wanted students to be involved, have fun, and not get too out of hand. She explained, "I guess just doing it helped me. It's a real important thing."

\section{Discussion}

What are the science teaching images and perceptions of preservice teachers entering our courses? They clearly espouse a definite view of teaching. Our students' drawings of themselves as science teachers indicated a strong orientation toward an individual who is in charge of classroomknowledge, resources, and the environment. That is to say, their drawings showed teachers in front of their students, erect, lecturing, and managing materials and students sitting in desks. This result is not very surprising in light of Goodlad's (1984) hallmark classroom study (conducted at about the time these students were in high school), which found a focus on teacher talk rather than student interaction. In fact, Goodlad's description of classroom activity time, textbooks, and questioning parallels the images our students brought to our methods courses.

Importantly, methods course field experiences continued to reinforce and shape our students' views of teaching. Their drawings, personal histories, and interviews further substantiated our conclusions about the images and perceptions of preservice teachers. Comments and reflections of preservice teachers indicated that their ideas about science teaching were highly correlated with specific, intense memories of their own science learning experiences in elementary, high school, and college science courses. It seems that throughout their science learning experiences, these students took opportunities to reinforce beliefs they formed early in their schooling experience regarding the nature of science teaching.

How do experiences and memories lead to the development of ideas, beliefs, and actions for teachers? Or, put another way, what filters individuals' beliefs into actions? Calderhead and Robson (1991) asserted that preservice teachers might be prone to use episodic images as recipes simply because they are novices lacking knowledge and experience. Additionally, Goodman's (1988) research determined that students tended to be most easily influenced by people and experiences that legitimated their "intuitive screen" ( $p$. 133). He worried about students being passive entities, 
not taking an active role in the development of their own occupational identity.

Pajares (1992) expressed similar concerns about preservice teachers as "insiders" (p.323) who need not redefine their situation. He explained that classrooms in colleges of education are similar to those classrooms students have known previously. "For insiders, changing conceptions is taxing and potentially threatening. These students have commitments to prior beliefs, and efforts to accommodate new information and adjust existing beliefs can be nearly impossible" (p. 323). Furthermore, it seems that early experiences more strongly influence judgments (in this case, elementary school learning experiences) and become theories or beliefs that are most highly resistant to change (Pajares, 1992). Thus high school and college experiences confirm theories or beliefs formed as early as elementary school. As Pajares noted, preservice teachers' beliefs "play a pivotal role in their acquisition and interpretation of knowledge" (p. 328) and "unexplored entering beliefs may be responsible for the perpetuation of antiquated and ineffectual teaching practices"'(p.328).

Barnes (1992) proposed that the most effective teachers have multiple interpretive frames to help them see more alternatives and make better choices. To change one's beliefs, teachers need to discover their existing frame for understanding what happens in their classroom is only one frame of several possible frames. Clearly, we need to help our students make explicit their personal theories about science teaching and learning. So how do we begin to challenge, reconstruct, and change the perceptions and belief of preservice teachers? Pajares (1992) explained that a number of conditions must exist before a student can accommodate conflicting information:

First, they must understand that new information represents an anomaly. Second, they must believe that the information should be reconciled with existing beliefs. Third, they must want to reduce inconsistencies among the beliefs. And last, efforts at assimilation must be perceived as unsuccessful. No small wonder, they argued, that conceptions are seldom weakened by anomalies. Students are generally unaware of their anomalies. In addition, if and when conceptual change takes place, newly acquired beliefs must be tested and found effective, or they risk being discarded. (p. 321)

\section{Science Methods Focused on Reform}

Clearly, teacher educators must enable students to confront, shift, and refine the beliefs, knowledge, values, and assumptions that form their personal theories about teaching and learning (Bryan, Abel, \& Anderson, 1996b). Methods courses might focus on the following suggestions.

Explore entering ideas and perceptions. Certainly, teacher preparation programs need to develop strategies for helping students reflect on their ovm and fellow students' perspectives. Goodman (1988) learned that this reflection must necessarily go beyond what students "believe." He found, "If their beliefs: were challenged in a non-threatening manner, most stidents seemed willing to seriously consider alternative points of view" (p. 130). He also found that opportunity for experimentation in field placements, reading, ciscussions, and conferences with faculty members encouraged students to explore their beliefs.

Provide a sound theoretical base. If methods faculty members continue to challenge students to reconsider their own personal theories of teaching and learning, without providing anything reasonable and sound to replace their own personal theories, we can only expect that they will fall back on the experiences (episodic memories) that created the personal theories in the first place. Students of education must be able to draw on their own knowledge base developed over the past decades and incorporate it into current theories of learning and teaching. In this, students must be guided in defining their personal theories about science learning and teaching and be able to help them reconstruct these theories based on new, reform-based theories of teaching and learning.

Uncover implicit theories. Clark (1988) advocated revisiting students' misconceptions and replacing them with scientifically correct conceptions. Fle reasoned that teachers' implicit theories are similar to students' preconceptions. "Both are robust, idiosyncratic, sensitive to the particular experiences of the holder, incomplete, familiar, and sufficiently pragmatic to have gotten the teacher or student to where they are today" (p. 7). Unfortunately, methods faculty members often talk of the reflection, but do little to provide the correct conceptions to replace the implicit theories preservice teachers hold.

Introduce multiple perspectives. Methods faculty members must be able to support multiple perspectives of the learning-teaching interface. A historic approach to teacher education, presenting a single cultural view to the exclusion of others, may indeed contribute to the reproduction of existing instructional patterns and superficial learning (Pajares, 1992). Students must understand not only the nature of science but the nature of learners and the differences they bring to the classroom. Clark (1988) suggested that methods 
faculty members discover students' preconceptions about teaching and learning and structure early field observations in the teacher preparation program to help make visible those important aspects of teaching that were not so obvious to them as primary or high school students. He recommended a changed faculty role to encourage students to question their own thinking, perceptions, decisions, and intentions.

\section{DASTT-C as a Window}

Given these research findings and aforementioned recommendations, the DASTT-C could be a useful tool to help teachers recollect memorable episodes within their own ideas, beliefs, and personal theories about how to teach elementary science, consider alternative theories, and work toward a preferred image of themselves as elementary science teachers. This preferred image could provide a strong foothold in the continued development of enhanced self-efficacy and outcome expectancy. Certainly, science educators must provide opportunities for prospective teachers to examine critically their beliefs, personal theories, and the knowledge they bring, as well as those they reinforce during teacher preparation programs. Obviously, this is but one aspect in what we see as key components to any teacher preparation program. However, if preservice teachers can begin to grasp the very nature of who they are in the scheme of what learning and teaching is about, change may be at hand.

As Lortie (1975) suggested, biography may be a critical factor in learning to teach, as teachers are both educated and socialized by the teaching models they witness over the thousands of hours they spend as learners in the classroom. We see the DASTT-C as another tool to build a biographical understanding of self. The biographical narratives and interviews of this research also added an opportunity for prospective teachers to reflect on the ways in which their learning experiences impacted their personal theories and teaching beliefs. In all, there seems to be a consensus that change in teachers' personal theories and beliefs is unlikely to occur without a great deal of purposeful, systematic inquiry about their personal theories, beliefs, and practice.

\section{Implications}

Reform documents of recent decades advocate a shift in teaching focus-from teacher-centered to studentcentered teaching. Sawada et al. (2002) measured significantly enhanced student learning in such reformed classrooms. Preservice teachers in this current study were not yet reformed. They still held to ideas and beliefs they developed before college. How, then, can elementary science teacher preparation programs hold to the responsibility of bringing new teachers into new, reformed understanding? How can preparation programs be more directly involved in helping students reframe their thinking (as suggested in Figure 1)?

Class size may be critical. Smaller classes would allow greater opportunity for reflective interactions with university professors. Bryan and Abell (1999) focused on helping one student identify the tensions between her ideals and her actual practice. Continued purposeful, systematic reflection enabled this student to change her practice in ways that reflected her beliefs about students as active, engaged participants in science learning. One-on-one coaching may seem unrealistic, but someone needs to focus prospective teachers on systematic reflection - to help them navigate perturbing encounters in productive ways and to continue to inquire into their own practice throughout their careers. Unchallenged, prospective teachers will continue to seek out experiences and explanations that resonate with teaching ideas and beliefs formed during their $\mathrm{K}-12$ years as students.

Changed beliefs may not be possible. Consider that students begin their methods course with firmly held ideas and beliefs about science teaching and learning. Students might begin the journey or gather the tools to begin the process, but perhaps such a change cannot take place in the 15 weeks of one methodscourse semester. Consider that even if the university classroom learning experiences are more student-centered than preservice students knew in their own K-12 student experiences, their elementary classroom field experiences will most likely mirror their elementary experiences. In this common programmatic definition, preservice teachers may develop a new vision while keeping traditional practice beliefs intact. Fuller (1969) argued that education courses may be answering questions students are not asking. First year teachers are primarily taken over with self-concerns (self-protection and self-adequacy) and, thus, little concerned with instructional design or assessment of student learning topics presented in education courses.

Richardson (1990) suggested that neither the learning-to-teach literature nor the teacher-change literature provide the necessary framework to bring about significant and worthwhile change. She argued, though, that teachers change all the time. The problem is "the degree to which teachers engage in the dialogue concerning warranted practice and take control of their classroom activities and theoretical 
justifications" (p. 16). This reflective process may begin in preservice programs - but must continue throughout teachers' professional careers.

\section{References}

Barnes, D. (1992). The significance of teachers' frames for teaching. In T. Russell \& H. Munby (Eds.), Teachers and teaching: From classroom to reflection (pp. 9-32). New York: Falmer Press.

Bryan, L. A. \& Abell, S. K. (1999). Development of professional knowledge in learning to teach elementary science. Journal of Research in Science Teaching, 36(2), 121-139.

Bryan, L. A., Abell, S. K., \& Anderson M. A. (1996a, January). Coaching reflective practice among preservice elementaryscience teachers. Paper presented at the Annual Meeting of the Association for the Education of Teachers in Science, Seattle, WA.

Bryan, L. A., Abell, S. K., \& Anderson M. A. (1996b, March). Preservice teachers' thinking about science teaching and learning: Experiences, frames and tensions. Paper presented at the Annual Meeting of the the National Association for Research in Science Teaching, St. Louis, MO.

Bullough, R. V. (1994). Personal history and teaching metaphors: A self-study of teaching as conversation. Teacher Education Quarterly, 21(1) 107-120.

Bullough, R. V., Jr., \& Knowles, J. G. (1991). Teaching and nurturing: Changing conceptions of self as teacher in a case study of becoming a teacher. Qualitative Studies in Education, 4, 121-140.

Calderhead, J. (1988). The contribution of field experiences to student primary teachers' professional learning. Research in Education, 40, 33-49.

Calderhead, J., \& Robson, M. (1991). Images of teaching: Student teachers' early conceptions of classroom practice. Teaching and Teacher Education, 7, 1-8.

Chambers, D.W. (1983). Stereotypic images of the scientist: The Draw-A-Scientist Test. Science Education, 67(2), 255-265.

Clark, C.M. (1988). Asking the right questions about teacher preparation: Contributions of research on teacher thinking. Educational Researcher, 17(2), 5-12.

Creswell, J.W. (1994). Research design: Qualitative and quantitative approaches. Thousand Oaks, CA: Sage.

Czerniak, M. C., Lumpe, A. T., \& Haney, J.J. (1999). Science teachers' beliefs and intentions to implement thematic units. Journal of Science Teacher Education. 10(2), 123-145.

Dewey, J. (1904). The relation of theory to practice in education. In J. Boydston (Ed.) John Dewey: The middle works (Vol. 3, pp. 249-272). Carbondale: Southern Illinois University Press.

Dewey, J. (1938). Experience in education:. New York: Macmillan.

Duemer, L., Fontenot, D., Gumfory, K., Kallus, M., Larsen, J., Schafer, S., \& Shar, B. C. (2002, Fall). The use of online synchronous discussion groups to enhance community formation and professional icentity development [Electronic version]. Journal of Interactive Online Learning, 2, 1-14.

Finson, K. D., Beaver, J. B., \& Cramond, B. L. (1995). Development and field test of a checklist for the Draw-a-Scientist Test. School Science and Mathematics, 95(4), 195-205.

Fuller, F. F. (1969). Concerns of teachers: A developmental conceptualization. American Educational Research Journal, 6(2), 207-225.

Goodenough, F.L. (1926). Measurement of intelligence by drawings. New York: Harcourt Brace.

Goodlad, J.I. (1984). A place called school: Prospects for the future. New York: McGrav-Hill.

Goodman, J. (1988). Constructing a practical philosophy of teaching: A study of preservice te^ıchers' professional perspectives. Teaching and Teacher Education, 4, 121-137.

Lincoln, Y., \& Guba, E. (1985). Naturalistic inquiry. Beverly Hills, CA: Sage.

Lortie, D.C. (1975). School-teacher: A sociological study. Chicago: University of Chicago Press.

Merriam, S. (1998). Case study research in education: A qualitative approach. San Francisco: Josey Bass.

Nespor, J. (1987). The role of beliefs in the practice of teaching. Journal of Curriculum Studies, 19, 31.7-328.

Norman, D. A. (1983). Some observations on mental models. In D. Gentner, \& A. L. Stevens, (Eds.), Mental models (pp. 7-14). Hillsdale, NJ: Lawrence Erlbaum Associates.

Pajares, M. F. (1992). Teachers' beliefs and educational research: Cleaning up a messy construct. Review of Educational Research, 62(3), 307-332.

Raizen, S. A., \& Michelsohn, A.M.(Eds.). (1994). The future of science in elementary schools: Educating prospective teachers. San Francisco: Jossey-Bass.

Richardson, V. (1990). Significant worthwhile change in teaching practice. Educational Researcher, 19(7) 10-18. 
Sawada, D., Piburn, M. D., Judson, E., Turley, J., Falsoner, K., Benford, R., \& Bloom, I. (2002). Measuring reform practices in science and mathematics classrooms: The reformed teaching observation protocol. School Science and Mathematics, 106(6), 245-253.

Simmons, P.E., Emory, A., Carter, T. Coker, T., Finnegan, B., Crockett, D., et al. (1999). Beginning teachers: Beliefs and classroom actions. Journal of Research in Science Teaching 36(8), 930-954.

Spradley, J.P. (1980). Participant observation. New York: Holt, Rinehart \& Winston.

Strauss, A., \& Corbin, J. (1990). Basics of qualitative research: Grounded theory procedures and techniques. Newbury Park, CA: Sage.

Thomas, J. A., \& Pedersen, J. E. (1998, January). Draw-a-science-teacher: $A$ visualization of beliefs and self-efficacy. Paper presented at the meeting of the Association for the Education of Teachers of Science, Minneapolis.

Thomas, J. A., Pedersen, J. E, \& Finson, K. (2001). Validating the Draw-a-Science-Teacher-Test Checklist
(DASTT-C): Negotiating mental models and teacher beliefs. Journal of Science Teacher Education, 12(4), 295-310.

Ullrich, W.(1999a). Integrative teacher education curriculum. Paper presented at the Annual Meeting of the National Middle School Association, Orlando, FL.

Ullrich, W. (1999b). Depth psychology, critical pedagogy, and initial teacher preparation. Teaching Education, 10(2), 17-33.

Yin, R. K. (1995). Case study research: Design and methods. Newbury Park, CA: Sage.

Editors' Note: Correspondence concerning this article should be addressed to Julie A. Thomas, Texas Tech University, Box 41071, Lubbock Texas 79409-1071.

Electronic mail may be sent via Internet to julie.thomas@ttu.edu 